\title{
CHARACTER AND CANDOR REQUIREMENTS FOR FCC LICENSEES
}

\author{
RALPH S. BRown, JR.**
}

The Communications Act explicitly makes the applicant's character an element in licensing. Applications must "set forth such facts as the Commission by regulation may prescribe as to the citizenship, character, and financial, technical, and other qualifications of the applicant to operate the station." Even in the absence of such guidance, the Commission could scarcely ignore evidence of bad character in making its ultimate determination whether a grant will serve the "public convenience, interest, or necessity." 2 The Act mentions the related problem of misrepresentation only in connection with the Commission's power to revoke licenses. ${ }^{3}$ Misrepresentation, or lack of candor, may, nevertheless, be treated as a defect of character, or as an independent ground for finding that public interest does not call for licensing someone who deceives the licensing authority. There is, it will appear, not much question about the Commission's power to demand high standards of truthfulness and candor as well as of character. There is also little doubt that, at least for the last decade, the Commission has set high standards. The questions that merit attention are rather these:

I) In what circumstances is the power exercised?

2) Is it abused, either by the Commission or by parties who bring before the Commission unwarranted charges of bad character or of deception?

3) If there are abuses, how can they be checked?

It may be said at the outset, without trying to prefigure any recommendations in conclusion, that there appear to be two forms of excessive concern with character and candor. The first is a tendency of parties, in hard-fought comparative pro. ceedings, to dredge up remote and far-fetched charges of any conceivable kind of wrongdoing. The second, in which the Commission has taken the lead, is to make questionable inquiries about radical or subversive political associations. Examples of these practices will emerge from the discussion that follows.

* B.A. I935, LL.B. I939, Yale University. Member of the New York bar; Professor of Law, Yale University.

${ }^{1} 48$ STAT. I085 (1934), 47 U.S.C. $\$ 308$ (b) (1952).

${ }_{4}^{3} 8$ STAT. 1083 (1934), 47 U.S.C. $\$ 307$ (a) (1952).

a Section 312 originally provided that "any station license may be revoked for false statements cither in the application or in the statement of fact which may be required by section 308 hereof. . . "48 STAT. 1086 (1934). The $x 952$ amendments changed this to read "false statements knowingly made . . .," 66 STAт. 716, 47 U.S.C. § 312 (a) (1952), apparently as part of a general intention to restrict the revocation power to cases of "acts willfully, knowingly, or repeatedly committed." Communications Act Amendments, 1952, H.R. REp. No. 2426, 82d Cong., 2d Sess. 20 (1952). The little-used revocation power, in either version, seems to have had no influence on application and renewal policics. 


\section{Misrepresentation}

Though the varieties of misrepresentation are infinite and its detection is sometimes difficult, identification of what constitutes misrepresentation is ordinarily not too difficult. The licensee (taking original, renewal, and transfer proceedings as the same for this purpose) will have submitted the prescribed forms, and, if there was a hearing, will have given testimony. Suppose the application recites that a corporation has paid-in capital, in the form of cash, in the amount of $\$$ ro,000. It has Ioo shares of stock, held in certain proportions by Doe, Moe, and Roe. Investigation, by the Commission's Broadcast Bureau or by a competitor, discloses that the bank balance is in fact only $\$ 1000$, and that Moe and Roe are nominees of Woe, with no beneficial interest themselves in the enterprise. Unless, as is unlikely, the applicant can satisfy the Commission that these misstatements are the result of innocent error, we have here a recurrent pattern of deception designed to mislead the Commission about the financial adequacy of the applicant and the identity of its principals. ${ }^{4}$

These are both matters of concern to the Commission, though it is perhaps not necessary that they should be to justify denying the application. In the landmark case of FCC $v$. WOKO, the Supreme Court said that "the fact of concealment may be more significant than the facts concealed. The willingness to deceive a regulatory body may be disclosed by immaterial and useless deceptions as well as by material and persuasive ones." ${ }^{5}$ In this case, the Court gave great emphasis to the Commission's power to demand complete candor. Unknown to majority shareholders, the general manager of WOKO had repeatedly concealed from the Commission something he either knew or should have known, that 24 per cent of the stock was beneficially held by Pickard, a vice president of CBS. Pickard's supposed motive in causing his interest to be concealed was "to prevent the facts from becoming known to Pickard's Columbia colleagues." The Commission denied a renewal of the license on this ground alone, refusing to hear any evidence about the station's performance, or to approve a reorganization that would have preserved the financial equity of the other shareholders. The Court of Appeals for the District of Columbia ruled that the Commission had acted arbitrarily, especially since there was no showing that Pickard would not have been acceptable to it as a stockholder. ${ }^{7}$ But the Supreme Court held that the Commission did not have to give weight to the various mitigating factors. "We agree," Justice Jackson commented, "that this is a hard case, but we cannot agree that it should be allowed to make bad law." Another element that made the case a hard one was that the Commission, in a number of earlier renewal cases, had been forgiving of similar concealments,

\footnotetext{
'E.g., both applicants were disqualified on such grounds in Balboa Radio Corp., 9 PIrE \& Fischer RAdio REg. 649 (1953) [hereinafter cited as "R.R."]

329 U.S. 223,227 (1946).

Id. at 225-26.

I53 F.2d 623 (D.C. Cir. 1946). Some of the facts are taken from this opinion.

329 U.S. at 229.
} 
even when they went so far as to effect transfers of control. But, the Court said, "the very fact that temporizing and compromising with deception seemed not to discourage it, may have led the Commission to the drastic measures here taken to preserve the integrity of its own system of reports."

Following this clear mandate, the Commission has been rather exacting in its assessment of misrepresentation. Sometimes it is taken as a sufficient sole ground for denying an application. More often there will be other grounds as well. Only occasionally will the Commission excuse a misrepresentation, as when there is a clear showing that some of the parties in an application have been imposed on by an associate, and have corrected the situation. Thus, shortly after WOKO, a misrepresentation about ownership was attributed to bad advice from a lawyer; the principals dispensed with his services, and the renewal was granted. ${ }^{10}$ But when two lawyers experienced in Commission practice concealed their interest, with the connivance of another stockholder (who had been a member of the old Federal Radio Commission), renewal was denied. ${ }^{11}$

It is unnecessary to accumulate examples of what may be considered routine deception. The considerable number of cases chiefly involve matters that are clearly called for by the Commission's questionnaires-financing, control, and broadcast experience. "Immaterial and useless deceptions," which the Supreme Court said could be considered because of their bearing on "willingness to deceive," have rarely been considered.12 This statement assumes that materiality is initially determined simply by the Commission's call for the information. Whether the correct information would have altered the disposition of the case is not the test of materiality. Súch a test was suggested by the Court of Appeals in WOKO; but it would lead to endless speculation, and cannot be correct.

The issues that develop in a hearing may be more extensive than the written submissions. Especially when the hearing assumes an adversary character because it is comparing the qualifications of competing applicants, or because other licensees intervene, a great number of issues of uncertain relevance and materiality may be introduced. To be sure, "willingness to deceive" may be inferred from evasive answers, faltering recollection, and other aspects of a witness's demeanor, no matter what the questions. This is related to credibility, which the hearing examiner must appraise for any witness. But a multiplication of issues blurs the fairly clear boundaries of misrepresentation that have been outlined so far. Suppose it is alleged that a party mismanaged a receivership which he held for a few years during the great de-

${ }^{\circ}$ Id. at 228. See Note, Broadcast License Revocation for Deception and Illegal Transfer, 15 Geo. WASH. L. REv. 425 (1947), for the cases before WOKO.

: ${ }^{10}$ Kanawha Valley Broadcasting, 3 R.R. 1977 (1948); cf. Lycoming County Broadcasting, 4 R.R. 264 (1948).

${ }^{11}$ Broadcasting Scrvice Organization (WORL), 3 R.R. 979 (1947).

12329 U.S. at 227. See 2 R.R. If 53.24 (digest of FCC misrepresentation decisions). An exceptional case which was remanded to the Commission for failure to take account of an alleged misrepresentation with respect to antenna location and network affiliation is Hall v. FCC, 237 F.2d 567 (D.C. Cir. 1956). The Commission affirmed its earlier decision. Spartan Radiocasting, I3 R.R. 6roa (1957). 
pression. From confused testimony about remote and complex events, a further charge is made that he misrepresented the facts, or that he was not completely candid about them. At this point, unless the transcript and the examiner's appraisal of demeanor clearly show "willingness to deceive" pervading the testimony, it becomes appropriate to inquire whether the facts are either relevant or material. And this, in many instances, requires consideration of character. What kinds of flaws in an applicant's past should be subjected to scrutiny? What must he be candid about?

\section{II}

\section{Character Measured by Vuolations of Law}

"Character" is such an amorphous trait that the Commission has not, so far as I know, attempted to define it comprehensively. The regulations simply require that an applicant must show that he "(or the person or persons in control of an applicant corporation or other organization) is of good character and possesses other qualifications sufficient to provide a satisfactory public service."13 The application form for broadcasters requires information about pending cases or convictions of "felony or other crime involving moral turpitude" and violations of lottery, antitrust, and unfair competition laws. If a comparative hearing is held, a further statement, of unspecified content, about an applicant's "background" is required. This, in practice, usually amounts to a short biography. ${ }^{14}$

In the leading case on the subject of character qualifications, Mester v. United States, Judge Moscowitz said that "a person's 'character' is usually thought to embrace all the qualities and deficiencies regarding traits of personality, behavior, integrity, temperament, consideration; sportsmanship, altruism, etc. which distinguish him as a human being from his fellow men."15 What the case directly involved was the relevance, in a transfer application, of the transferees' misconduct in their edible oil business. Their products had been the subject of several condemnations under the Food and Drug Act and related state statutes. The firm had accepted a Federal Trade Commission cease and desist order for false advertising and had settled an OPA proceeding for violation of ceiling prices. These matters, moreover, were misrepresented in the FCC hearing. The court held that the limited requirements of the application form and of the regulations did not preclude adverse consideration of these matters, and that "character' includes involvement in civil litigation and includes a person's disposition to be ingenuous and truthful."16 The Supreme Court affirmed without opinion.

Fortified by this decision and by the subsequent Mansfield Journal case, which held that the Commission could properly disqualify an applicant whose newspaper attempted to suppress competition for advertising from a radio station, ${ }^{17}$ the Com-

${ }^{13} 47$ C.F.R. $\S 3.24$ (b)(4) (I956 Supp.).

${ }^{16}$ FCC Form 301, I pt. 2 R.R. 10r; FCC Public Notice 53-r36r, Oct. 14, 1953, id. at 98:91.

${ }^{15}$ 7o F. Supp. II8, I22 (E.D.N.Y. 1947), aff'd por ctriam, 332 U.S. 749 (1947).

${ }^{10} 70 \mathrm{~F}$. Supp. at 124 .

${ }^{17}$ Mansfield Journal v. FCC, r80 F.2d 28 (D.C. Cir. 1950); cf. Lorain Journal Co. v. United States, 
mission has given considerable attention to the law-abiding qualities of applicants. Obedience to laws, to be sure, is only one aspect of good character, but some degree of objectivity is possible in determining whether a person has violated the law, certainly more than can be attained in assessing his "... sportsmanship, altruism, etc."

This does not mean that violations of law are an automatic index to character. In 1951, the Commission attempted to formulate a "Uniform Policy as to Violation by Applicants of Laws of the United States." Its Report on the subject readily conceded that "no blanket policy should be enunciated." The Report did point out, however, that the applicable principles related equally to federal, state, and local laws, and that these principles required an appraisal, in the context of other qualifications and circumstances, of the willfulness, recency, and frequency of the violations. The Report said that it made no difference whether the violation was found in a civil or criminal case, and, indeed, declared that it was not decisive whether there had been any adjudication. It was the facts, the conduct of the applicant, that would have to be considered. ${ }^{18}$

The 195I Report gave special attention to violations of the antitrust laws. Because "Congress conceived as one of the Commission's major functions the preservation of competition in the radio field," the Report concluded that the Commission "must be concerned" about the applications of "persons who have engaged in monopolistic practices in other industries." The special problems of antitrust violations do have roots in the Communications Act ${ }^{10}$ that are separate from the taproot of "character" relied on in Mansfield Journal. In practice, consideration of antitrust violations creates a richness of embarrassments for applicants from certain industries, notably (as the Report recognized would be the case) those connected with the major motion-picture companies. Indeed, a proceeding in which the Commission was exploring both the possible control of Dumont by Paramount Pictures, and the proposed transfer of control of American Broadcasting to United Paramount Theatres, got so involved that the Commission attempted to confine the introduction of antitrust matters. It announced that ordinarily, with respect to applicants who were "existing licensees with records as broadcasters," it would exclude antitrust violations not directly involving radio communications if they had occurred more than three years before the application was filed. ${ }^{20}$ This attempt at a time limitation required two clarifying memoranda in the Paramount case and has not been applied in comparative hearings. This large exception to the three-year rule was announced in the Denver television case. There, principals of both applicants had movie exhibition interests, which led to extensive but indecisive consideration of their antitrust in-

342 U.S. I 43 (I95I) (similar conduct by same party supported antitrust conviction); Note, 59 YALI L.J. 1342 (1950). Cf. Columbia Amusement Co., I2 R.R. 509 (1956), aff'd on rehearing, id. at $572 a$ (1957) (applicant who owned all movie theatres in area lost out to applicant with newspaper and radio interests, largely because of predatory competitive practices).

${ }^{28}$ I pt. 3 R.R. 9x:495 (I95I).

${ }^{10} 48$ STAT. 1087,47 U.S.C. 5 313-4 (1952).

${ }^{20}$ Paramount Pictures, Inc., 8 R.R. 135 (1952); clarifying mems., id. at 139, 140a. 
volvements; no disqualification resulted. ${ }^{21}$ In the Portland (Oregon) television case, one of the applicants was Westinghouse Broadcasting, whose parent company had a considerable antitrust history. The Commission here took occasion to say that it attached no significance to consent decrees, pleas of nolo contendere, or allegations in pending cases. All that the I95I Report called for was facts of law violations. ${ }^{22}$

When multiple licensees like Westinghouse and the networks get into a case, the antitrust issues begin to lose whatever independent significance they might have as indicators of character and are more directly related to questions of concentration in the broadcast field. This is illustrated by the controversial episode of NBC's exchange of its television station in Cleveland for a Westinghouse station in Philadelphia, which was approved by the Commission but led to the filing of a civil antitrust case against NBC charging violation of section I of the Sherman Act. ${ }^{23}$

In a quite different field, violation of state prohibition laws has raised a difficult ethical problem for the Commission. J. S. Love, Jr., a hotel operator in Biloxi, Miss., was awarded a radio license in 1947 despite a showing that he, along with others in the Gulf Coast resort area of Mississippi, openly ignored the state's prohibition law. A majority of the Commission thought that the de facto nullification of the law was in accord with community sentiment and that Love's conduct did not reflect adversely on his character. At that time, the Commission's policy on violation of law was somewhat vacillating. ${ }^{24}$ A decade later, after the cases and Report already described, Love's radio station lost out in a comparative hearing for a television license. Other grounds were found to be decisive by the Commission, but again the prohibition issue figured largely. A stockholder of the successful competitor was also a hotel operator, though the dispensing of alcohol in his hotel was apparently conducted with more circumspection than in Love's. However, the examiner found that this innkeeper, unlike Love, was not in control of the applicant, and focused on Love's character. Again, the virtual abrogation of the prohibition law in the community was established. Further light was cast on morality in Mississippi by consideration of the state's "black market tax," which boldly seeks revenue from the liquor traffic by imposing a tax of ten fer cent on the sale of anything the sale of which "is prohibited by law." Though Love summoned a parade of eminent character witnesses, including the Governor and the Dean of the University of Mississippi Law School, the examiner, distinguishing between reputation and character, concluded that Love's character must be eroded by his persistent violations and awarded a preference on this point to the other applicant. However, the Commission, after reviewing the evidence, decided that no question of "character qualifications, absolute or comparative, [was] presented" as to either innkeeper. It quoted an observa-

21 Aladdin Radio \& Television, 9 R.R. I (1953).

22 Westinghouse Radio Stations, Io R.R. 878, 964 (1955).

2s FCC, Public Notice Mimeo. No. 27067, Dec. 28, r955; see House Committee on the Judiciary, Report of the Antitrust Subcommittee on the Television Broadcasting Industry, 85th Cong., Ist Sess. 97108 (1957). The District Court dismissed the complaint. See N.Y. Times, Jan. 11, 1958, p. 37, col. I.

26 WGCM, 3 R.R. 956 (1947). See Harry P. Warner, Radio \& Television LaW 19I-95 (1948), on this and carlier cases. 
tion of counsel that in Mississippi, "the Drys have their laws; the Wets have their liquor; the State has its revenues," and made its award on the basis of superior experience and integration of ownership and management. ${ }^{25}$

The appraisal of illegal conduct, though unavoidable, can be troublesome. It also opens the way for parties in comparative hearings to comb the pasts of their opponents for instances of misconduct. Thus, in the Denver television case, one participant had been a promoter of "Bank Night," a cash drawing for moviegoers that had a great vogue in the I930's, survived several state lottery prosecutions, but expired in the face of a federal postal proceeding. ${ }^{26}$ In view of the Commission's long-standing concern with lotteries, this incident was probably relevant, though remote; but it was given little weight in the decision. The disposition of more far-fetched charges will be considered in the concluding section of this paper, after another source of them has been considered.

\section{III}

\section{Character Measured by Opinions and Associations}

Published opinions as evidence of character were accepted with some hesitation in the New York Daily News FM case. The American Jewish Congress had attempted a content analysis of the News' editorial column to demonstrate antisemitic bias. Because the study was unscientifically prepared, the Commission found it had no probative value; the issue was its admissibility. The Commission decided that admissibility of the study would not constitute any infringement of freedom of the press. It also denied that it contemplated any examination of the applicant's beliefs; though it did need to know 'whether he is likely to give a 'fair break' to those who do not share them." The editorials were equated to past behavior rather than to expressions of belief. ${ }^{27}$

In the succeeding years, the kinds of behavior, expressions, and attitudes that came to dominate public attention were those relating to communism. In this area, associations with supposedly subversive individuals and organizations became a subject of equally intense interest. The Commission's staff was, of course, subject to loyalty tests and investigations. Other agencies of the Government began to impose loyalty tests for benefits within their control-for passports, for research grants, for honorable discharges from the armed forces. ${ }^{28}$ It is not altogether surprising that the Commission felt stirrings in this direction. In early 1955, after preliminary moves in 1954, a report was issued discussing proposed regulations for those holding amateur and commercial operators' licenses (but not for broadcasters). Present membership in the Communist Party, in any organization required to register under the Internal

\footnotetext{
${ }^{25}$ Radio Associates, 10 R.R. 1073 (1957), supplanting hearing examiner's decision of x956, formcrly at same page. The quoted passages from the Commission's decision are on pp. 1108 and togo. An appeal is pending.

${ }^{20}$ Aladdin Radio \& Television, 9 R.R. I, 35 (1953); see S. C. Oppenheimer, Unfair Trade Practices 85 I (1950) ("Bank Night" cases).

${ }^{27}$ WBNX, 4 R.R. 242 (I948); see Comment, I5 U. Chr. L. REv. 910 (1948).

${ }^{28}$ See Comm'n on Government Security, Report, passim (1957).
} 
Security Act of 1950 , or in any other organization advocating violent overthrow of the Government would be disqualifying. In addition, a requirement of "good moral character" was to be introduced, backed up by questions inquiring about conviction for crime, and about membership at any time in disqualifying organizations. The significance of past membership would be explored in a hearing. The report touched only casually on the possible security reasons for the charges. These rules would have affected hundreds of thousands of people, and some opposition developed. One source of concern appeared to be the disclosures that would be required of ex-convicts, for whom amateur radio seems to be an important avenue of rehabilitation. ${ }^{29}$

Though the rules were never put into effect, it came to light in a $195^{6}$ hearing that the Commission was putting similar questions on a selective basis. Lafferty, holder of a commercial operator's license in connection with work as a mobile radio installer in San Francisco, was asked, when he applied for a renewal, to answer questions about past or present membership in the Communist Party or "Communist organizations." Lafferty refused to answer, challenging the Commission's authority to ask such questions. In the absence of a specific regulation, the hearing examiner was forced to rely on the Commission's general power to prescribe qualifications for operators. He found that loyalty was a reasonable qualification, that present membership in the Communist Party would be disqualifying, and that in refusing to answer a question on this point the applicant did not meet the burden on him of affrmatively establishing his qualifications. Again, security questions relative to the improper use of radio transmitters were only slightly explored. ${ }^{30}$ On December 18 , 1957, the Commission made a decision substantially upholding the hearing examiner.

Meanwhile, the Edward Lamb case, shortly to be discussed, was in violent eruption, so that parties to comparative hearings began to perceive possible advantages in raising loyalty issues. In the Boston television case, charges were extensively aired that an officer of one applicant had had "a connection with certain questionable organizations." He at first denied it, but on reviewing his records conceded that at times from I944 to I947, he had made contributions to the Joint Anti-Fascist Refugee Committee (which is on the Attorney General's list) and to the Southern Conference on Human Welfare ("cited" by the House Committee on Un-American Activities). The opposing parties disclaimed any imputation of disloyalty, but suggested that the connections indicated bad judgment. The Commission found that a finding on this point was not warranted, since the officer had been diligent in withdrawing his support when the organizations were attacked. ${ }^{31}$

In the Seattle television case, a number of character charges were made, including the following with respect to one applicant. First, in the r930's a radio station controlled by him had broadcast speeches by one Howard Costigan on behalf of the

${ }^{20}$ I pt. 2 R.R. 63:ix (1955).

${ }^{80} \mathrm{Re}$ Lafferty, I3 R.R. 64I (1956). It was stipulated in this case that similar questions had been put to some, but not all, applicants.

${ }^{01}$ WHDH, 13 R.R. 507, 537 (1957), appeal pending. 
Washington Commonwealth Federation. The Federation was put on the Attorney General's list in 1949, and Costigan testified in 1948 that he had been a Communist from 1937 to 1940 . The Commission said there was no showing that the applicant had known of these matters at the time of the broadcasts. Second, from I925 to 1928 the applicant had been an editor and part-owner of the Seattle Record, a labororiented newspaper, which, it was said, had exhibited pro-Russian and pro-Communist sympathies. The Commission disposed of this charge by finding that the excerpts submitted from the paper did not constitute an adequate content analysis. ${ }^{32}$

In these episodes, the significance of the associations was considered apart from any question of misrepresentation. But in the outstanding case dealing with charges of Communist beliefs, sympathies, and associations, that of Edward Lamb, a framework of misrepresentation was dominant. This, while it complicates analysis, also emphasizes a suggestion made earlier that questions of character and of misrepresentations about character may have to be considered together, especially when the emotion-charged issue of loyalty arises.

IV

\section{The Lamb Case}

Edward Lamb is a Toledo lawyer and businessman of kaleidoscopic interests and abilities. He was one of the founders of the National Lawyers' Guild. He was also one of the pioneers in commercial television, and in 1948 , got a license for WICU in Erie, Pennsylvania, where he also owned a newspaper. He owns several other radio and television stations and has recently engaged in some spectacular corporate operations, including an unsuccessful attempt to get control of the Seiberling Rubber $\mathrm{Co}^{33}$

- In the 1930's, and also during the war, he was on the letterheads of several front organizations. Whether he took a more active role in any of them was never clearly settled. They included the International Labor Defense and the American League Against War and Fascism. His law practice and political activities in Toledo brought him into contact with people who he may have known were Communists. Indeed, he made a speech at the dedication of new Communist headquarters in Toledo-but that was in 1944, when the Party was in its wartime guise as the Communist Political Association, and the theme was unity. Back in 1934, after a visit to Russia, he had published a careless and laudatory book about the Soviet experiment.

Lamb's career has not been one to deprive him of enemies; on several occasions, he had had to fight off opposition both inside and outside the FCC. His political associations have inevitably been used against him. In a 1948 hearing, he answered interrogatories denying Communist affiliations and associations. The charges at this

${ }^{33}$ Queen City Broadcasting, 15 R.R. 645, 712 (1957).

${ }^{33}$ See Lincoln, Ted Lamb, Toledo Riddle, Fortune, May 1956, p. 144. Parts of this and the last section of this paper are drawn from my forthcoming book on loyalty and security tests for employment, to be published by the Yale University Press. 
time were apparently derived from the book and the front affliations. ${ }^{34}$ When WICU's license came up for renewal, the Commission charged, in 1954, that Lamb's earlier answers and affidavits were false and that, moreover, he had been a Communist Party member from 1944 to 1948 . The issue was framed as one of misrepresentation. After an unsuccessful attempt by Lamb to enjoin the Commission, ${ }^{35}$ the case went to a hearing, amid loud outcries from Lamb and from the general counsel of Lamb Enterprises, former Attorney General J. Howard McGrath, that Lamb was being persecuted.

These protests, as the hearing proceeded, seemed to have some substance. The Broadcast Bureau produced in support of its charge as sorry a collection of unreliable and mendacious witnesses as have appeared in any recent loyalty case. Lamb's array of counsel demonstrated the value of cross-examination by discrediting some and refuting others. Finally, the case practically blew up when two witnesses recanted and accused Commission representatives of suborning perjury. One of them, an unbalanced woman, was promptly indicted and convicted-not for the substance of her testimony, either for or against Lamb, but for making false statements about the government attorneys. ${ }^{36}$ The hearing examiner, in recommending that the license be renewed, charitably absolved the FCC of bad faith in instigating the proceeding, observing that "the picture of Lamb which emerges is one of uncertain authenticity -that of a shrewd, successful and aggressive lawyer who was connected in some way with several Communist-dominated matters which, despite his recognized acumen, he failed to recognize." However, he concluded, "there is no proof that Lamb personally engaged in any subversive activity."37

The Commission, a year and a half later, granted the license in a very careful decision which emphasized that "the sole purpose of the inquiry . . . has been to determine the truthfulness of statements made to the Commission by Mr. Lamb." His argument that "the Commission had no right to inquire into past associations, activities and beliefs," the decision said, "must be rejected."38 The facts had to be ascertained to settle the question of misrepresentation. After observing that the sweeping character of the answers and affidavits was Lamb's own doing, the decision concluded that the denials could not be considered knowingly false, with respect to the associations and affiliations. As for the book, neither it nor some other writings that were brought into the case contained illegal advocacy of violent overthrow; and since the book had been published and available since 1934, it was hardly a subject for misrepresentation.

\footnotetext{
34 The 1948 matter, see 4 R.R. I29, I3 R.R. 239, was apparently not reported; but see WBNX, 4 R.R. 242, 255 (1948) (dissent discusses Lamb issues).

${ }^{35}$ Lamb v. Hyde, 223 F.2d 646 (D.C. Cir. I955).

${ }^{30}$ Natvig v. United States, 236 F.2d 694 (D.C. Cir. 1956). See N.Y. Times, Feb. 17, 1955, p. 12, cols. 5,6 ; id. Feb. 18 , 1955, p. 13, cols. 5, 6. Time, March 21, 1955, p. 94

${ }^{87}$ The hearing examiner's initial decision, originally in 13 R.R. 237 (1955), has been removed and the Commission's decision substituted. Facts are drawn from both decisions. Neither makes any direct reference to the sensational stricken testimony.

${ }^{28}$ Dispatch, Inc., 13 R.R. 237, 274 (1957).
} 
The Broadcast Bureau further charged that Lamb lacked "forthrightness and candor." He had, indeed, been much more cautious in his testimony than in his public declarations. The hearing examiner found this excusable in the light of the extravagant accusations that had been made-accusations that are not mentioned in the decision because the testimony in which they occurred was stricken. The Commission simply put to one side the question of candor, since it was not formally in issue. $^{39}$

There was one other issue that the Commission itself had raised, namely, the good faith of accusations by Lamb that Commission investigators had offered a bribe and had stated that they were out to "get" Lamb. These accusations had been publicly made and figured in Lamb's attempt to enjoin the Commission. Since the bases for them turned out to be either flimsy or mistaken, the Commission was very severe about this attack on its integrity. But it concluded, a little self-righteously in view of the excesses on both sides of the case, that a licensee under serious charges of misrepresentation probably could not take an objective view of the Commission's duties; so his intemperance was forgivable. ${ }^{40}$ Thus ended the $\operatorname{Lamb}$ case.

\section{Concluding Observations}

The hornet's nest of the Lamb case, and the outcome of the Lafferty case, invite questions whether there are any limits to the Commission's power to demand information, and to deny a license if the information is refused or misleadingly disclosed. Without challenging the proposition that misrepresentation per se is relevant, an applicant should be able at least to deprecate the weight of deceptive information if the Commission had no right to demand it in the first place. Lamb had perhaps waived this point by protesting his innocence too much.

Straightforward refusals to answer may be justified if the information which is demanded I) has no relevance to any qualifications the Commission may legally consider; or 2) unreasonably inhibits freedoms of religious or political belief, expression, or association protected by the first amendment. These general propositions overlap to the extent that some inquiries in the area of first amendment freedoms may be tolerated if they are relevant to the qualifications expected of a broadcast licensee. For example, the Commission made an adverse character determination in one case because the applicant, a clergyman, was found to be "intemperate in his writings, sermons and broadcasts ... an expert in vituperation and vilification." 11 The disappointed applicant might have argued that denial of a prized license would inhibit his peculiar, but constitutionally-protected, way of spreading the Word; but the Commission could reply that the restraint, if any, was indirect, and that the judgment bore directly on its obligation to find that the licensee would be a fair broadcaster.

In the political sphere, the Commission might reasonably conclude that a present member of the Communist Party might attempt to misuse his license by broadcasting

${ }^{39} \mathrm{Id}$. at 287 .

${ }^{10} \mathrm{Id}$. at 289 .

41 Independent Broadcasting Co. v. FCC, $x 93$ F.2d 900,902 (D.C. Cir. 1951). 
propaganda. On the other hand, it should be pointed out that commercial broadcasters operate in a goldfish bowl; their performance is intended to be heard or seen. Opportunities for subversive propaganda by a station owner are confined, first by the resistance of his audience, and second by Commission procedures that purport to evaluate the quality of a licensee's operation. However, these arguments apply to any prejudgment of qualifications; they need not prevent the Commission from anticipating trouble.

There is also a security argument, dimly suggested in the Lafferty case, that is. applicable to Communists as holders of either broadcast or operator's licenses. Radiotransmitters are important tools of espionage. A licensed transmitter would have some advantages over an illicit one for point-to-point communications, because its. emissions would not immediately arouse suspicion. It is also theoretically possible that coded messages could be concealed in the output of commercial broadcasters. A station owner, however, would arouse suspicion if he attempted to dictate the exact language of broadcasts. Employees such as disc jockeys would be in a far better position to convey secret messages. Does this suggest a conclusion that everyone with access to a microphone should be screened? If it does, the implausibility of wholesale employment tests as protection against a rather special espionage hazard is. revealed. These matters and the related possibility of sabotage during an emergency are the province of counterintelligence agencies. Questionnaires from the FCC are not a very potent weapon.

Nevertheless, the existing disabilities of Communists are so numerous and feelings. against them run so high that the Commission, given the broad reach of its power. to appraise character, would probably be upheld in denying a license either to an established member of the Party or to someone independently identified as an advocate of violent overthrow. Once this step is taken, however, the tortuous problems of proof and identification are opened up. Is it then appropriate to inquire about affliations with front or satellite organizations, about associations with suspect persons, about readings and writings as indicators of loyalty, about beliefs themselves? That is what other major undertakings to ferret out Communists, and subversive or disloyal persons however defined, have come to.

Here the first amendment problem, to which the Commission should be especially sensitive as the guardian of the most potent media of expression, comes in again. The Commission presumably could not give any consideration to whether an applicant was a Republican or a Democrat, a Unitarian, or a Catholic. If it could not, it could not insist that the applicant disclose such facts, first because it has no authority to collect random information, and second because even an indirect abridgement of first amendment rights would hardly be countenanced when it was clearly capricious. As inquiries relating to Communism reach into activities having no taint of illegality, they at some point cross the bounds of authority. Just where that point lies one can scarcely predict in view of the changing judicial and legislative scene. 
What such uncertainty suggests is that this is a good area for administrative selfrestraint. Especially in the case of an applicant with extensive and varied experience as a broadcaster, like Edward Lamb, it seems quite unnecessary ever to have embarked on an exploration of his admittedly unconventional politics. And as for analyzing a book he wrote in I934, what was its possible relevance to his qualifications in 1954? If the applicant has no broadcast record, his politics are still of no concern to the Commission, unless political activities have carried the applicant into violations of law. His public record of expression may be relevant to his probable conduct as a broadcaster. Still, the New York Daily News decision was borderline. One may find the editorial policies of even such a successful paper detestable; but it would be a delicate matter to judge them officially. Commissioner Coy, defending the constitutionality of the decision against an invocation of Near v. Minnesota, ${ }^{42}$ pointed out that though the scurrilous journal there involved may have been privileged against prior restraint, it could not have qualified for a broadcast license. ${ }^{43}$ True enough; but the Commission, when it inquires into any kind of opinion or lawful association, soon gets on thin ice.

If the Commission set a good example, it could then more readily discourage private parties from introducing damaging material of remote relevance. In the Boston television case, the cartoonist $\mathrm{Al} \mathrm{Capp} \mathrm{was} \mathrm{a} \mathrm{small} \mathrm{stockholder} \mathrm{of} \mathrm{one} \mathrm{appli-}$ cant and a member of one of a series of committees that the applicant had assembled to bolster its program policies. Another applicant urged the Commission to consider that a New York legislative committee was said to have condemned his ubiquitous comic strip! The Commission gravely avoided the issue by finding that Capp was not in control. ${ }^{44}$

It may be suggested that this is too mild a disposition of such foolishness. The Commission has several other choices open to it, any one of which may be appropriate, depending on the seriousness of the attempted mud-slinging:

r) It may ignore the charge altogether as irrelevant. There can hardly be a legal obligation to make findings on everything the parties dredge up.

2) If the charges have received public attention and are not supported, it can, in effect, rehabilitate the injured applicant. A recent hearing examiner's decision in a minor case took great pains to deal with wild fraud charges because the successful applicants, "duly ordained ministers of the Baptist Church," were, in his opinion, "entitled to have a full and complete disclosure of the facts and circumstances which led to their being charged publicly with having practiced fraud and deceit" on the Commission. ${ }^{45}$

3) It may, in a comparative hearing, award a demerit to an applicant who makes irresponsible charges. This the Commission at first did in the Hartford television

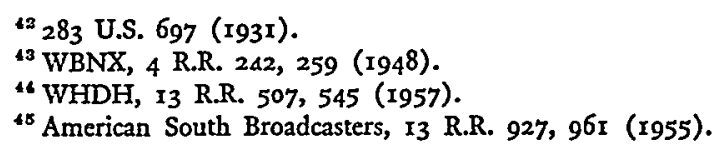


case; but it later amended the decision and, without receding from its criticism of the charges, did not make them part of the preferences that counted against the unsuccessful applicant. ${ }^{46}$

4) In an extreme case, it can strike the entire document containing the charges. ${ }^{47}$

The legitimate scope of inquiries into character and candor are extensive enough, without making them a vehicle for calumny and for needless inquisition.

10 'Travellers Broadcasting Service, I2 R.R. 689, 788 (1956), amended I5 R.R. 299 (I957).

${ }^{4}$ Crescent Bay Broadcasting, 6 R.R. I84 (1950). 